Onkologie 1987;10(suppl 1):1

\title{
Inhalt, Vol. 10, Supplement 1, 1987
}

$\begin{array}{ll}\text { Impressum } & 3 \\ \text { Vorwort } & 4 \\ \text { Diagnostik } & 5\end{array}$

Vorsorgeuntersuchungen bei klinisch unauffälliger Mamma

(«Screening»)

5

Physikalische Untersuchungsmethoden zur Differential-

diagnose klinisch verdächtiger Befunde

5

Markierungsmethoden für verdächtige Befunde

Zusatzuntersuchungen bei der klinischen Diagnose: «Sezernierende Brust beidseits»

6

Kontrolluntersuchungen nach klinisch verdächtigem, jedoch

histologisch benignem Befund

Operatives Vorgehen in der Primärtherapie des

Mammakarzinoms

7

Vorbemerkung

7

Operation bei proliferierender Mastopathie mit Atypien

und Carcinoma in situ (Stadium Tis)

Infiltrierendes Karzinom (eingeschränkt radikale Mastekto-

mie)

8

Behandlung bei fortgeschrittenen Primärtumoren oder bei

bereits bestehender Metastasierung

Hormonrezeptorbestimmung

Lymphknotenstatus

9

Tumordokumentation

Bilaterales Mammakarzinom

Organerhaltende Primärbehandlung des Mammakarzinoms ...

Aufbauplastik nach Brustamputation

10

Pathologisch-anatomische Untersuchung von

Mamma-Amputationspräparaten und axillärem Fettgewebe ...

Mamma

10

Axilläres Fettgewebe 11

TNM-Klassifikation des Mammakarzinoms (Stadieneinteilung)

Postoperative (adjuvante) Behandlung des Mammakarzinoms

nach eingeschränkt radikaler Mastektomie

12

Allgemeines

12

Adjuvante Chemo- oder Hormontherapie

Postoperative Strahlentherapie

Protokoll für die postoperative Strahlentherapie 
Zusammenfassung der Entscheidungsfindungen für die post operative Therapie beim Mammakarzinom 16

Nachsorge nach Mastektomie 17

Tumormarker 18

Benutzung des Nachsorgekalenders 18

Physikalisch-therapeutische Maßnahmen nach

Brustkrebsoperationen 19

Physikalisch-therapeutische Maßnahmen und Beratung in der postoperativen, stationären Phase

Physikalisch-therapeutische Maßnahmen und Beratung in der physischen und psychischen Erholungsphase

Physikalisch-therapeutische Maßnahmen und Beratung bei chronischen Beschwerden 26

Physikalisch-therapeutische Maßnahmen bei metastasenbedingten Beschwerden

Rezeptierungshinweise 27

Mammakarzinom und Schwangerschaft 28

Mammakarzinom in der Schwangerschaft

Schwangerschaft nach der Behandlung eines Mammakarzi noms 29

Behandlung des lokoregionalen Tumorrezidivs

Systemische Therapie des melastasirrten Mammakarzinoms . . Prognosekriterien 30

Allgemeine Regeln der systemischen Therapie beim Mam makarzinom 30

Systemische Therapie bei Patientinnen mit günstigen

Prognosekriterien in der Prämenopause 32

Systemische Therapie bei Patientinnen mit günstigen

Prognosekriterien in der Postmenopause 32

Systemische Therapie bei Patientinnen mit ungünstigen

Prognosekriterien in der Prämenopause

Systemische Therapie bei Patientinnen mit ungünstigen

Prognosekriterien in der Postmenopause 32

Hormonelle Therapiemaßnahmen 33

Zytostatische Therapie 33

Richtlinien zur Anpassung der Zytostatika-Dosierung ... Indikationen für eine Strahlentherapie und/oder für ein operatives Vorgehen im metastasierten Stadium Zusätzliche Behandlungsmaßnahmen 36

Hirnmetastasen 36

Karzinomatöse Höhlenergüsse

Hyperkalzämie 36

Schmerzen 38

Kriterien der Erfolgsbeurteilung

Remissionsbeurteilung (Anlehnung an UICC-Kriterien) . . 38 Skelettszintigraphische und röntgenologische Bewertungs- 
kriterien beim Mammakarzinom $\quad 39$

Beurteilung der Patientenaktivität $\quad 40$

Inflammatorisches Mammakarzinom (entzündliches Mamma

karzinom) $\quad 40$

Behandlung im lokoregionalen Stadium $\quad 40$

Behandlung im metastasierten Stadium 40

Paget-Karzinom der Brust $\quad 41$

Stadieneinteilung $\quad 41$

Therapie 41

Mammakarzinom des Mannes

42

Lokoregionales Stadium $\quad 42$

Metastasiertes Stadium 42

Literatur 42

Mitglieder der Projektgruppe Mammakarzinom

ONKOLOGIE

Zeitschrift für Krebsforschung u. -behandlung

unter Fortführung der

«Österreichischen Zeitschrift für Onkologie»

Supplement 1 zu Band 10, Februar 1987

Contents

Imprint 3

Preface 4

Diagnostics 5

Medical Check-up in the Breast without Pathological

Findings (Screening) 5

Physical Methods of Examination for Differential Diagnosis

of Clinically Suspicious Findings

5

Methods of Marking in Suspicious Findings 5

Additional Examinations in the Clinical Diagnosis: “"Bilater

ally Secreting Breast” 6

Control Examinations after Clinically Suspicious but Histo-

logically Benign Findings 6

Operative Methods in Primary Therapy of Breast Carcinoma . . 7

Introduction 7

Operation in Proliferating Mastopathy with Atypias and

Carcinoma in Situ (Stage Tis) 8

Infiltrating Carcinoma (Limited Radical Mastectomy) ... 8

Treatment of Progressive Primary Tumors or together with

Existing Metastazation

Hormone Receptor Determination

9

Lymphnode State

9

Tumor Documentation 9

Bilateral Breast Carcinoma 9

Organ-Conservation Techniques in Primary Therapy of "Small"

Breast Carcinoma 10

Reconstructive Plastic Surgery after Amputation of the Breast 
Pathological-Anatomical Examination of Mamma-Amputation Preparations and Axillary Adipose Tissue $\quad 10$

Mamma 10

Axillary Adipose Tissue

TNM-Classification of Breast Carcinoma (Staging)

Postoperative (Adjuvant) Treatment of Breast Carcinoma after

Limited Radical Mastectomy

General Remarks

12

12

Adjuvant Chemotherapy or Hormonal Therapy

Postoperative Radiotherapy

14

Procedure for Postoperative Radiotherapy

14

Summary of Deciding Indications in Postoperative Therapy

of Breast Carcinoma 16

Follow-up after Mastectomy

Tumormarkers

Use of Follow-up Calendar

18

Physicotherapeutical Measures after Breast Carcinoma

Operations

19

Physicotherapeutical Measures and Consultation in the

Postoperative Clinical Period 24

Physicotherapeutical Measures and Consultations in the

Physical and Psychical Recovery Period 24

Physicotherapeutical Measures and Consultation in Chronic

Complaints 26

Physicotherapeutical Measures in Metastases-Involved

Complaints 27

Prescription Suggestions

28

Breast Carcinoma and Pregnancy 28

Breast Carcinoma during Pregnancy 28

Pregnancy after Treatment of Breast Carcinoma

Treatment of Locoregional Recurrence 29

Systemic Therapy of Metastasized Breast Carcinoma

Prognosis Criteria

30

General Rules of Systemic Therapy in Breast Carcinoma . . 30

Systemic Therapy in Patients with Favorable Prognosis

Criteria during Premenopause

32

Systemic Therapy in Patients with Favorable Prognosis

Criteria during Postmenopause

Systemic Therapy in Patients with Unfavorable Prognosis

Criteria during Premenopause

32

Systemic Therapy in Patients with Unfavorable Prognosis

Criteria during Postmenopause

32

Hormonal Therapeutic Measures

33

Cytostatic Drug Therapy

33

Guidelines for the Dosage of Cytostatic Drugs

Indications for Radiotherapy and/or for Operative Measures in 
Metastasized Stage

Additional Treatment-Measures

Brain Metastases

36

Carcinomatous Cavernous Effusions

36

Hypercalcemia 36

Pain 38

Criteria of Response

38

Remission Assessment (Following UİCC Criteria)

Bone-Scintigraphical and Radiological Assessment-Criteria

in Breast Carcinoma

39

Judgment of Patient Activity

40

Inflammatory Breast Carcinoma

40

Treatment during the Locoregional Stage

Treatment during the Metastasized Stage

Paget-Carcinoma of the Breast

41

Staging

41

Therapy

41

Male Breast Carcinoma

42

Locoregional Stage

42

Metastasized Stage

42

References

42

Members of the Project-Group “'Breast Carcinoma”

43 1987;010:1 